\author{
Bolesław Cieślik \\ Ministerstwo Sprawiedliwości
}

\title{
MATERIAŁY POMOCNICZE NA EGZAMINIE NA TŁUMACZA PRZYSIĘGŁEGO
}

\begin{abstract}
Zarys treści: Artykuł jest próbą odpowiedzi na pytanie, jakie materiały pomocnicze są dopuszczalne na egzaminie na tłumacza przysięgłego w świetle dosyć nieprecyzyjnych przepisów Rozporządzenia Ministra Sprawiedliwości w sprawie szczegółowego sposobu przeprowadzenia egzaminu na tłumacza przysięgłego. Wspomniany akt prawny dopuszcza w części pisemnej egzaminu korzystanie przez kandydatów ze słowników, nie precyzując jednak tego pojęcia. Posiłkując się poglądami teoretyków leksykografii, autor artykułu stara się przeanalizować dopuszczalność korzystania na egzaminie z kilku dostępnych dzieł leksykograficznych, które wprawdzie mają w tytule określenie „słownik”, jednak po przebadaniu treści okazuje się, że nie zawsze są słownikami.
\end{abstract}

Słowa kluczowe: tłumacz przysięgły; słownik; materiały pomocnicze

Dretekstem do napisania niniejszego artykułu była skarga złożona przez jedną z osób przystępujących do egzaminu na tłumacza przysięgłego języka angielskiego. Skarżący w piśmie skierowanym do przewodniczącego Państwowej Komisji Egzaminacyjnej stwierdził:

Jakim prawem na egzaminie odebraliście mi Słownik Polsko-Angielski Terminów Prawnych Polterm z definicjami wydany przez Translegis i pod auspicjami TEPIS [...], a jest to przecież typowy słownik i nazywa się wyraźnie „Słownik”. Naruszyliście moje prawo do posiadania papierowego słownika. Podszedł do mnie osobnik i odebrał mi słownik, a jakie miał do tego prawo?

${ }^{1}$ Ministerstwo Sprawiedliwości, Wydział Tłumaczy Przysięgłych, sygn. DZP-V-672-102/13; pisownia zgodna $z$ oryginałem. 
No właśnie, czy Komisja postąpiła słusznie, nie zezwalając na posłużenie się wymienionym wyżej słownikiem?

Rozporządzenie Ministra Sprawiedliwości z dnia 24 stycznia 2005 r. w sprawie szczegółowego sposobu przeprowadzenia egzaminu na tłumacza przysięgłego ustanawia normę ogólną, że „W czasie egzaminu niedozwolone jest korzystanie przez egzaminowanego z materiałów pomocniczych, a w szczególności ze słowników, podręczników i innych opracowań, a także pomocy innych kandydatów" ( $\$ 3$ ust. 1), oraz normę szczególną, dotyczącą tylko części pisemnej egzaminu: „W czasie egzaminu pisemnego kandydat może korzystać z przyniesionych przez siebie słowników” ( 33 ust. 2).

Wydaje się zatem, że skoro rozporządzenie dopuszcza posługiwanie się na egzaminie pisemnym słownikami, to odwołujący miał rację. Jednak wspomniane rozporządzenie nie precyzuje, czym jest „słownik”. Spróbuję zatem przyjrzeć się przyjętym w teorii leksykografii definicjom tego terminu, a następnie sprawdzić na przykładzie kilku publikacji, w których tytułach pada określenie „słownik”, czy rzeczywiście każdy słownik to słownik.

Już na pierwszy rzut oka widać, że panuje w tym zakresie chaos. Zarówno w polskiej, jak i niemieckiej nauce i praktyce spotkać można publikacje o podobnych tytułach $\mathrm{z}$ treścią o różnym charakterze, jak i publikacje $\mathrm{z}$ treścią o podobnym charakterze, jednak $\mathrm{z}$ różnymi tytułami.

Wir haben da zunächst Wörterbuch, Lexikon, Enzyklopädie, enzyklopädisches Wörterbuch, Sprachwörterbuch, Sachwörterbuch, Fachwörterbuch, Fachlexikon usw. In Wirklichkeit herrscht hier wenig Klarheit, weder als Konsensus bei der tatsächlichen Namensgebung von Nachschlagewerken, noch in der metalexikographischen Diskussion (Bergenholtz 1996, s. 733)².

Jednak analizując publikacje metaleksykograficzne, można rozpoznać ogólny konsensus co do charakteru dzieł tworzonych przez leksykografów praktyków i uznanie za podstawowe dwa rodzaje takich dzieł - z jednej strony „słownik”, a z drugiej „encyklopedię”.

Klasyczne rozróżnienie między słownikiem a encyklopedią sformułował pod koniec XIX wieku brytyjski filolog Henry Sweet: „The fundamental difference between a dictionary and a cyclopedia is, that the dictionary has

2 „Mamy tu zatem słownik, leksykon, encyklopedię, słownik encyklopedyczny, słownik językowy, słownik rzeczowy, słownik specjalistyczny, leksykon specjalistyczny itd. Tak naprawdę sytuacja jest niejasna, nie ma zgody zarówno w praktycznym nadawaniu tytułów dziełom leksykograficznym, jak i w dyskusjach metaleksykograficznych” - tłumaczenie własne. 
to explain words, the cyclopedia has to explain things" (cyt. za: Engelberg, Lemnitzer 2009: 11) ${ }^{3}$. Taki podział uznawany jest także przez polskich leksykografów. Według Tadeusza Piotrowskiego „zwykle wyróżniamy dwa główne rodzaje dzieła leksykograficznego: słownik i encyklopedię, przy czym słownik standardowo traktuje o języku, zaś encyklopedia o świecie" (Piotrowski 2001: 37). Autor ten wskazuje na różnice w doborze haseł w obydwu rodzajach publikacji.

W encyklopedii nie znajdziemy w ogóle pewnych wyrazów jako haseł, np. wyrazów najczęstszych w danym języku. [...] Nie znajdziemy także w encyklopediach np. czasowników, ponieważ encyklopedie zajmują się najczęściej obiektami (Piotrowski 2001: 40).

Inni polscy autorzy dokonują podobnych rozróżnień, chociaż czasami posługują się odmienną terminologią. Na przykład Kania i Tokarski używają terminów „słownik językoznawczy” i „słownik encyklopedyczny”. Według tych autorów

w słownikach językoznawczych definicje informują przede wszystkim o znaczeniu i zakresie użycia wyrazów hasłowych, przy czym w wielu wypadkach odwołują się do ich budowy słowotwórczej (tzw. definicje strukturalne, np. atomowy - przymiotnik od atom, czytanie - forma rzeczownikowa od czasownika czytać) (Kania, Tokarski 1984: 231).

\section{Natomiast}

słowniki encyklopedyczne zawierają objaśnienia nie wyrazów, lecz rzeczy i zjawisk nazywanych wyrazami, informują o treści pojęć odnoszących się do tych rzeczy i zjawisk. Dlatego w słownikach encyklopedycznych nie ma na ogół takich wyrazów, jak zaimki, przyimki, spójniki, partykuły i wykrzykniki. Nie ma też tak abstrakcyjnych wyrazów, jak przymiotniki, przysłówki i czasowniki, o ile nie wchodzą one w skład nazw złożonych. Natomiast w słownikach encyklopedycznych spotyka się wiele imion własnych (np. nazwisk pisarzy, uczonych, polityków, kompozytorów itp.), a także nazw państw, miast, mórz, rzek, gór itp. (Kania, Tokarski 1984: 231).

3 „Fundamentalna różnica między słownikiem a encyklopedią polega na tym, że słownik ma objaśniać wyrazy, a encyklopedia ma objaśniać rzeczy” - tłumaczenie własne. 
Również Igor Burkhanov wprowadza pojęcie nadrzędne reference work, które dzieli na dictionaries i encyclopedias, podkreślając różnice w doborze haseł i sposobie ich opisu. Według tego autora słownik

is meant to provide information about the structure of a language or languages sufficient for correct linguistic usage, the history of lexical unit [...], grammatical information, as well as any linguistic data that the dictionary user may find useful ${ }^{4}$ (Burkhanov 2010: 74).

Natomiast encyklopedia „is primarly intended to furnish information about the world, i.e. to provide detailed specifications of objects, phenomena, and their relations to other objects and phenomena" (Burkhanov 2010: 74) ${ }^{5}$.

Także niemieccy badacze uznają taki dwupodział, wyróżniając leksykografię językową - Sprachlexikographie oraz encyklopedyczną - Fachlexikographie. Autorzy publikacji Lexikographie und Wörterbuchbenutzung tak zdefiniowali słownik i encyklopedię:

Wörterbuch: Datensammlung mit äußerer Zugriffsstruktur, die sprachliche Angaben zu lexikalischen Einheiten wie Wörtern, Wendungen, Morphemen etc. oder zu Begriffen enthält (Produkt der Sprachlexikographie).

Enzyklopädie: Datensammlung mit äußerer Zugriffsstruktur, [...] mit Sachinformationen zu lexikalischen Einheiten (Produkt der Sachlexikographie) (Engelberg, Lemnitzer 2009: 6, 7) .

\section{Według Britty Nord}

die Trennung zwischen Sprach- und Sachlexikographie [...] beruht auf der Unterscheidung zwischen der Information über sprachliche Zeichen durch sprachliche

${ }^{4}$, „[... [ ma przedstawić informacje o strukturze języka lub języków, wystarczające do prawidłowego używania języka; wiadomości dotyczące historii jednostki leksykalnej [...]; informacje gramatyczne oraz wszelkie dane językowe, jakie użytkownik słownika mógłby uznać za użyteczne" - tłumaczenie własne .

${ }^{5}$ „[...] ma przede wszystkim przedstawić informacje o świecie, np. dostarczyć dokładnych opisów przedmiotów, zjawisk i ich związków z innymi przedmiotami i zjawiskami” - tłumaczenie własne.

${ }^{6}$ „Słownik: zbiór danych z zewnętrzną strukturą dostępu, który zawiera informacje językowe o jednostkach leksykalnych, takich jak słowa, zwroty, morfemy itd. lub o pojęciach (produkt leksykografii językowej).

Encyklopedia: zbiór danych z zewnętrzną strukturą dostępu, [...] z informacjami rzeczowymi o jednostkach leksykalnych (produkt leksykografii encyklopedycznej)” - tłumaczenie własne. 
Angaben einerseits und der Information über Gegenstände und Phänomene durch enzyklopädische Angaben andererseits (Nord 2002: 22) ${ }^{7}$.

Obok publikacji dających się jednoznacznie przyporządkować istnieje wiele dzieł pośrednich, zawierających elementy zarówno słowników, jak i encyklopedii, określanych różnymi mianami.

Dziełem pośrednim między słownikiem encyklopedycznym a słownikiem językoznawczym jest leksykon. Jeżeli najogólniejszym przeznaczeniem słownika językoznawczego jest podawanie znaczeń wyrazów, to leksykon może jeszcze oprócz tego zawierać informacje typu encyklopedycznego (Kania, Tokarski 1984: 232).

Podobnie niemieccy uczeni uznają konieczność wyróżnienia mieszanych publikacji leksykograficznych, np. Falber i Schaeder proponują określić je jako fachliche Allbücher.

Ein fachliches Allbuch ist [...] ein Fachwörterbuch, dessen genuiner Zweck darin besteht, daß ein potentieller Benutzer aus den lexikokgraphischen Daten Informationen zu den (fach-) sprachlichen Gegenständen und zu nichtsprachlichen Gegenständen (zu den Sachen im Fach) gewinnen kann (Felber, Schaeder, s. 778)

Z kolei Wiegand zaproponował inne określenie - Allbuch, który stanowi według tego autora osobny rodzaj dzieła leksykograficznego: „Die Allbücher können einer eigenen Klasse zugewiesen werden, die sich weder mit der Klasse der Sach- noch mit der Sprachwörterbücher überschneidet" (Wiegand 1988: 747) ${ }^{9}$.

Poza zakresem zainteresowania niniejszego artykułu pozostają definicje kognitywne, które mają „zdawać sprawę z tzw. naiwnego obrazu świata” (Żmigrodzki 2009: 185). Rozpatrywane słowniki i encyklopedie służyć mają bowiem pomocą tłumaczom tekstów prawniczych, gdzie wymagana jest wiedza precyzyjna, a używana terminologia możliwie ściśle zdefiniowana.

7 „Podział na leksykografię językową i encyklopedyczną polega na rozróżnieniu między informacją o znakach językowych za pomocą danych językowych z jednej strony a informacją o przedmiotach i zjawiskach przez dane encyklopedyczne z drugiej strony" - tłumaczenie własne.

8 „Fachliches Allbuch to [...] słownik specjalistyczny, którego celem jest umożliwienie potencjalnemu użytkownikowi uzyskania - za pomocą danych leksykograficznych - informacji o (specjalistycznej) rzeczywistości językowej oraz o rzeczywistości pozajęzykowej (przedmiotach, jakimi się dana dziedzina zajmuje)" - tłumaczenie własne.

9 „Allbücher mogą zostać przyporządkowane odrębnej klasie, której zakres nie pokrywa się ani z klasą słowników encyklopedycznych ani językowych" - tłumaczenie własne. 
Biorąc pod uwagę powyższe uwagi, spróbujemy poniżej przeanalizować kilka przykładów dzieł leksykograficznych, z których korzystają tłumacze specjalistycznych tekstów prawnych i prawniczych. Kiedy tłumacz albo badacz zaczyna przyglądać się ofercie wydawniczej pomagającej zrozumieć terminy prawnicze lub je tłumaczyć, dostrzega, że na rynku jest bardzo wiele tego typu publikacji. Po pierwsze, może się zaopatrzyć w dwujęzyczne słowniki specjalistyczne zawierające terminy prawnicze $\mathrm{w}$ języku polskim i ich odpowiedniki w danym języku obcym, czasami z kilkoma przykładami użycia w aktach prawnych. Takich słowników jest bardzo wiele, zarówno dla języków bardzo w Polsce popularnych, np. angielski, niemiecki, rosyjski i francuski, jak i rzadziej używanych, np. norweski czy słowacki. Co do dopuszczalności używania tych słowników w trakcie egzaminu na tłumacza przysięgłego nie ma żadnych wątpliwości. Są to klasyczne słowniki językowe, które stanowią podstawowe narzędzie pracy tłumacza. Pojawienie się kandydata na egzaminie na tłumacza przysięgłego bez takiego słownika świadczy o wielkiej niefrasobliwości takiej osoby i w zasadzie skazuje ją na niepowodzenie egzaminacyjne. Do najbardziej popularnych i dostępnych w księgarniach słowników tego rodzaju, których używają tłumacze języka angielskiego, należą:

- Słownik terminologii prawniczej i ekonomicznej angielsko-polski Janiny Jaślan i Henryka Jaślan (Jaślan, Jaślan 1999),

- Stownik prawniczy angielsko-polski polsko-angielski Jacka Gordona (Gordon 2011),

- Słownik terminologii prawniczej angielsko-polski Ewy Ożgi (Ożga 2006).

Natomiast w zakresie języka niemieckiego wymienić można przykładowo:

- Słownik terminologii gospodarczej. Bankowość, finanse, prawo Iwony Kienzler (Kienzler 2006),

- Słownik języka prawniczego i ekonomicznego Aliny Kilian (Kilian 2011),

- Słownik prawa i gospodarki Bogusława Banaszaka, Alexandra von Brünnecka, Tiny de Vries, Marcina Krzymuskiego (Banaszak i in. 2005).

Dalej mamy wydawnictwa encyklopedyczne, najczęściej jednojęzyczne, np. Wielka encyklopedia prawa pod red. Brunona Hołysta (Hołyst 2005), Encyklopedia prawa pod red. Urszuli Kaliny-Prasznic (Kalina-Prasznic 2006), Encyklopedia prawa administracyjnego pod red. Michała Domagały, Anny 
Haładyj i Stanisława Wrzoska (Domagała, Haładyj, Wrzosek 2010), Leksykon prawa morskiego. 100 podstawowych pojęć pod red. Doroty Pyć i Iwony Zużewicz-Wiewiórowskiej (Pyć, Zużewicz-Wiewiórkowska 2013) i wiele innych. Odpowiednikami takich publikacji w najpopularniejszych językach obcych byłyby - dla języka angielskiego Black's Law Dictionary (Garner 2011) czy dla niemieckiego Rechtswörterbuch (Creifelds 2004). Wymienione publikacje zawierają termin prawniczy, a następnie jego definicję w tym samym języku, np.

Abandon (ang. abandonment, niem. Abandon, franc. délaissement) jest instytucją $\rightarrow$ prawa ubezpieczeń morskich, którego istota polega na możliwości zrzeczenia się przez ubezpieczającego na rzecz ubezpieczyciela praw do przedmiotu ubezpieczenia, z jednoczesnym żądaniem zapłaty pełnej sumy ubezpieczenia przez ubezpieczyciela (Z. Brodecki, Prawo ubezpieczeń..., s. 82-85). Abandon uregulowany jest w Kodeksie morskim w tytule VIII dotyczącym ubezpieczenia morskiego, w jego dziale II poświęconym wykonaniu umowy ubezpieczenia (art. 330-335 KM) (Pyć, Zużewicz-Wiewiórkowska 2013).

W literaturze niemieckiej:

Baurecht. 1. B. im objektiven Sinne ist die Gesamtheit der die Bebauung von Grundstücken regelnden privatrechtlichen und öffentlichrechtlichen Rechtsvorschriften (Creifelds 2004) ${ }^{10}$.

Z przywołanych wyżej definicji widać wyraźnie, że mamy do czynienia $\mathrm{z}$ encyklopediami. Artykuły hasłowe opisują daną instytucję prawa, podają nazwy aktów prawnych, w których te terminy występują. W objaśnieniach nie ma natomiast w ogóle informacji językowych. Nie są to słowniki i - zgodnie z obowiązującymi przepisami - nie powinno się nimi posługiwać na egzaminie na tłumacza przysięgłego.

Po zebraniu powyższych informacji teoretycznych spróbujmy przyjrzeć się publikacji, którą przyniósł na egzamin na tłumacza przysięgłego przywołany na wstępie kandydat. Polsko-angielski słownik terminów prawnych Polterm $z$ definicjami Tomasza Borkowskiego (Borkowski 2011) jest określany przez autora jako „dwujęzyczny przekładowy branżowy słownik terminolo-

10 „Prawo budowlane 1. W rozumieniu obiektywnym - całość przepisów prawnych, zarówno prywatnoprawnych, jak i publicznoprawnych, regulujących zabudowę nieruchomości” tłumaczenie własne. 
giczny definiujący”. Nie wnikając w opisaną obszernie przez autora w słowie wstępnym mikrostrukturę haseł, należy stwierdzić, że słownik zawiera ponad 8000 haseł. Są to terminy prawne występujące w tekstach polskich aktów prawnych wraz z ekwiwalentami angielskojęzycznymi oraz dodatkowo nazwą aktu prawnego, w którym dany termin występuje, np.

Przestępstwo przeciwko życiu - offence against life; $z ́ r$. Civcod

Przetarg nieograniczony - open tendering; źr. Pubproclaw

Przychód - revenue; $z r$. Taxord

jakość pracy - work quality; $z ́ r$. Labcod

Są to $\mathrm{w}$ większości związki frazeologiczne $\mathrm{z}$ ośrodkiem rzeczownikowym, a więc wyrażenia. Obok wyrażeń występują także zwroty z ośrodkiem czasownikowym, np.

dać rękojmię - to give warranty; $z ́ r$. Insuractiv

przeszacować wartość zbytej inwestycji - revaluate investment; $z$ r. Account tworzyć rezerwę na ryzyko ogólne w ciężar kosztów - to establish general risk reserve do debit of costs; źr. Banklaw

Jak widać, są to terminy lub zwroty prawnicze mające swoje źródło $\mathrm{w}$ obowiązujących w Polsce aktach prawnych. Wprawdzie prócz angielskiego ekwiwalentu brak jakichkolwiek dodatkowych informacji językowych, nie ma tu żadnych wątpliwości, że przedstawione przykłady są typowymi artykułami hasłowymi dwujęzycznego słownika specjalistycznego.

Jednak obok przywołanych haseł omawiany słownik zawiera dodatkowe informacje. Jak wskazuje jego tytuł, obejmuje on także definicje. Zgodnie $\mathrm{z}$ informacją odautorską zawartą we wstępie publikacji takich definicji jest ponad 550 i dotyczą one podstawowych terminów hasłowych. Prezentowane definicje to albo definicje ustawowe, a więc takie, których źródłem jest obowiązujący w Polsce akt prawny, albo sformułowane przez autora słownika na podstawie przepisów oraz rozmaitych publikacji. Opis formułowany jest zawsze zarówno w języku polskim, jak i angielskim, np.

Def. Rękojmia za wady prawne oznacza odpowiedzialność sprzedawcy względem kupującego z tytułu umowy sprzedaży, jeżeli rzecz sprzedana stanowi własność osoby trzeciej albo jeżeli jest obciążona prawem osoby trzeciej; w razie sprzedaży praw sprzedawca odpowiedzialny jest także za istnienie tych praw; $z$ r. Ustawa Kodeks cywilny, art. $556 \$ 2$ 
Expl.: Warranty for legal defects means the liability of a seller to a buyer by virtue of a contract of sale if the thing sold is the property of a third party or if it is encumebered with a right of a third party; in the case of selling the rights, the seller is also liable of the existence of such rights; ref. PLC, Civil Code Act, Article $556 \$ 2$; alt. warranty of title (Borkowski 2011: 234).

Jak zauważył autor słownika, stanowi on „dla tłumacza źródło wiedzy językowej i merytorycznej w dwóch językach o kontekście terminu, poczynając od dziedziny [...], a kończąc na szerokim kontekście terminologicznym" (Borkowski 2011: XIII). Omawiany słownik jest zatem dziełem pośrednim między słownikiem językowym a encyklopedią, więc używając terminologii Kani i Tokarskiego, leksykonem. W języku niemieckim można go określić jako Allbuch (wg Wieganda) lub fachliches Allbuch (Fallberg, Schaeder). Tak więc postępowanie członka Państwowej Komisji Egzaminacyjnej wydaje się słuszne. Polsko-angielski słownik terminów prawnych Polterm $z$ definicjami, pomimo swojego tytułu nie jest słownikiem, lecz innego rodzaju dziełem leksykograficznym. Zatem nie spełnia on warunków umożliwiających posługiwanie się nim na egzaminie na tłumacza przysięgłego, określonych w rozporządzeniu Ministra Sprawiedliwości w sprawie szczegółowego sposobu przeprowadzania egzaminu na tłumacza przysięgłego.

$\mathrm{Na}$ tym stwierdzeniu właściwie artykuł powinien się kończyć. Jednak rodzą się pytania: Czy tak restrykcyjne podejście ma sens? Czy na pewno kandydaci przystępujący do egzaminu na tłumacza przysięgłego nie powinni mieć możliwości posługiwania się opisanymi powyżej publikacjami? Przecież w praktyce tłumaczenia prawniczego same dwujęzyczne słowniki prawnicze nie wystarczają i używanie innych prac, w tym o charakterze encyklopedycznym, świadczy o odpowiedzialności i uwadze tłumacza, wrażliwego na odmienności systemów prawnych. Wydaje się zatem godne polecenia liberalne podejście w dopuszczaniu dzieł leksykograficznych na omawianym egzaminie. Autor niniejszego artykułu proponuje rozszerzające rozumienie terminu „słownik” i objęcie nim, na potrzeby egzaminu, także pozostałych dzieł leksykograficznych o charakterze encyklopedycznym lub zawierających elementy zarówno słownikowe, jak i encyklopedyczne. Sytuacja egzaminacyjna będzie $\mathrm{w}$ takim przypadku bardziej zbliżona do rzeczywistości tłumacza pracującego $\mathrm{w}$ domu, a wykluczenie innego rodzaju pomocy naukowych, jak wzory pism, i tak będzie wystarczające, aby mieć pewność, że egzamin sprawdza rzeczywiste umiejętności kandydata. Wydaje się także, że dla zapewnienia klarownej sytuacji wskazana byłaby jednak interwencja prawodawcy i zmiana brzemienia przepisu $₫ 3$ ust. 2 wspomnianego rozpo- 
rządzenia i dopuszczenie posługiwania się także publikacjami o charakterze encyklopedycznym.

\section{Literatura}

\section{Akty prawne}

Rozporządzenie Ministra Sprawiedliwości z dnia 24 stycznia 2005 r. w sprawie szczegółowego sposobu przeprowadzenia egzaminu na tłumacza przysięgłego, Dz. U. Nr 15, poz. 129.

\section{Słowniki i encyklopedie}

Banaszak, B., von Brünneck, A., de Vries T., Krzymuski M., 2005, Słownik prawa i gospodarki. Tom II niemiecki-polski, Warszawa.

Borkowski, T., 2011, Polsko-angielski słownik terminów prawnych Polterm $z$ definicjami, Warszawa.

Creifelds, C. (red.), 2004, Rechtswörterbuch, München.

Domagała, M., Haładyj, A., Wrzoska, S., 2010, Encyklopedia prawa administracyjnego, Warszawa.

Garner, B. A., 2011, Black's Law Dictionary. Pocket Edition, Eagan-Rochester. Gordon, J., 2011, Słownik prawniczy angielsko-polski polsko-angielski, Warszawa.

Hołyst, B. (red.), 2005, Wielka encyklopedia prawa, Warszawa.

Jaślan, J., Jaślan H., 1999, Słownik terminologii prawniczej i ekonomicznej angielsko-polski, Warszawa.

Kalina-Prasznic, U., 2006, Encyklopedia prawa, Warszawa.

Kilian, A., Kilian, A., 2011, Słownik języka prawniczego i ekonomicznego, tom II polsko-niemiecki, Warszawa.

Kienzler, I., 2006, Słownik terminologii gospodarczej. Bankowość, finanse, prawo, Warszawa.

Ożga, E., 2006, Słownik terminologii prawniczej angielsko-polski, Warszawa.

Pyć, D., Zużewicz-Wiewiórkowska, I., 2013, Leksykon prawa morskiego. 100 podstawowych pojęć, Warszawa.

\section{Literatura przedmiotowa}

Bergenholtz, H., 1996, "Grundfragen der Fachlexikographie”, [w:] Euralex '96 Proceedings I-II Papers submitted to the Seventh EURALEX International Congress on Lexicography, M. Gellerstam, J. Järborg, S.-G. Malmgren, K. Norén, L. Rogström, C. Röjder Papmehl (red.), Göteborg, s. 731-758. 
Burkhanov., I., 2010, Lexicography. A Dictionary of Basic Terminology, Rzeszów.

Engelberg, S., Lemnitzer, L., 2009, Lexikographie und Wörterbuchbenutzung, Tübingen.

Felber, H., Schaeder, B., 1999, Typologie der Fachwörterbücher, [w:] Fachsprachen. Ein internationales Handbuch zur Fachsprachenforschung und Terminologiewissenschaft, L. Hoffmann, H. Kalverkümper, H.E. Wiegand (red.), Berlin-New York.

Kania, S., Tokarski, J., 1984, Zarys leksykologii i leksykografii polskiej, Warszawa.

Nord, B., 2002, Hilfsmittel beim Übersetzen. Eine empirische Studie zum Rechercheverhalten professioneller Übersetzer, Frankfurt am Main.

Piotrowski, T., 2001, Zrozumieć leksykografię, Warszawa.

Wiegand, H.E., 1988, „Was eigentlich ist Fachlexikographie? Mit Hinweisen zum Verhältnis von sprachlichem und enzyklopädischem Wissen", [w:] Deutscher Wortschatz. Lexikologische Studien. Ludwig Erich Schmitt zum 80. Geburtstag von seinen Marburgern Schülern, H.H. Munske, P. von Polenz, O. Reichmann, R. Hildebrandt (wyd.), Berlin-New York.

Żmigrodzki, P., 2009, „Najważniejsze zasady opisu znaczenia w «Wielkim słowniku języka polskiego»", [w:] Linguistica Copernicana, nr 1, s. 183-198.

\section{Auxiliary materials during the exam for sworn translators Summary}

The article is an attempt to decide which auxiliary materials are permitted during the state examination for sworn translators in view of vague provisions of the regulation of the Minister of Justice on proceedings binding for the sworn translator state examination. The aforementioned regulation stipulates that the candidates can use their own dictionaries during the written part of the examination, however, it does not explain or specify the term 'dictionary'. Many books including the word "dictionary" in their titles are in fact encyclopedias. This constitutes a problem for the examination board that has to decide and, if the need arises, to forbid, to use certain books similar in character, which tends to cause some objections on the part of some candidates. The analysis of theoretical approaches and the field literature allows the author to conclude that certain amendments to the Minister's regulation should be introduced to avoid any misunderstandings in the future.

Keywords: sworn translator, dictionary, auxiliary materials

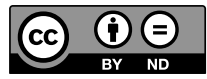


